\title{
Uterine Corpus Cancer Pathologic Primary Tumor TNM Finding v6
}

National Cancer Institute

\section{Source}

National Cancer Institute. Uterine Corpus Cancer Pathologic Primary Tumor TNM Finding v6. NCI Thesaurus. Code C61336.

A pathologic finding about one or more characteristics of uterine corpus cancer, following the rules of the TNM AJCC v6 classification system as they pertain to staging of the primary tumor. TNM pathologic primary tumor findings are based on clinical findings supplemented by histopathologic examination of one or more tissue specimens acquired during surgery. 